Bangl. J. Vet. Med. (2009). 7(2) : $332-340$

\title{
EPIDEMIOLOGICAL STUDY OF UDDER AND TEAT DISEASES IN DAIRY COWS
}

\author{
M. A. Uddin ${ }^{1 *}$, M. M. Kamal ${ }^{1}$ and M. E. Haque ${ }^{2}$ \\ ${ }^{1}$ Department of Livestock Services, Dhaka, Bangladesh, ${ }^{2}$ Department of Agricultural Statistics, \\ Bangladesh Agricultural University, Mymensingh-2202, Bangladesh
}

\begin{abstract}
An epidemiologic study was conducted on 581 dairy cows (indigenous and its crosses 371 , exotic crosses 210) of 4 government establishments to find prevalence of udder and teat diseases and their association with udder and teat characteristic, milk yield and milk flow rate in dairy cows. Mastitis $(25.5 \%)$ was most common disease followed by udder skin diseases $(15.0 \%)$ and teat diseases (12.6\%). Prevalence of injuries and other lesions was higher in the skin of fore left udder quarter $(22.7 \%)$ and teat $(17.7 \%)$ and rear left teat end (4.5\%). Mastitis was found to be associated with Sahiwal and Sindhi cross cow, poor body condition, bottle shaped teat, teat with round end, injuries and other lesions to the udder and teat skin and teat diseases. Udder skin diseases were strongly associated with indigenous cows, cow aged 5-10 years, small milk vein, larger front udder, and bottle shaped teats and flat end teats. Milk flow rate was higher in Sahiwal and Sindhi cross cows, large milk vein, larger front udder, funnel and cylindrical teats and pointed teat ends. Risk factors of udder and teat diseases, milk yield and milk flow rate in high yielding indigenous and its cross cows were not similar to those of exotic cows and their crosses. The relationship of udder and teat diseases; and udder and teat characteristics varies with the genetic composition of the dairy cows. Therefore, further genomic study needs to confirm association of udder and teat diseases with host characteristics.
\end{abstract}

Key words: Epidemiology, udder health, dairy cows, cross-sectional, mastitis, teat

\section{INTRODUCTION}

Bangladesh has a high number of cattle population (21.5 million) with about 3.33 million cows in milk (BBS, 2004). The udder and its teats are the most important physical assets of milch cow, which play a vital role in sustainable economic milk production. It is also recognized that the udder characteristics are very important in respect to milk production. Due to position, size, shape and anatomical feature of udder, the dairy cows are susceptible to infection and injuries, which results in mastitis (Shukla et al., 1997). The morphology of teat, especially apex and streak canal are recognized as parts of the passive defence mechanisms against intramammary infection.

Mastitis is defined as an inflammation of the mammary gland and is almost always associated with bacterial infection. It is one of the major problems of the dairy industry world wide including Bangladesh. It is also predominantly associated with some other risk-factors described elsewhere particularly on farms and cows (Kivaria et al., 2004; Van Schaik et al., 2005). Experience in mastitis control indicates that while the occurrence of inflammation in the udder may not be entirely preventable in all cows within herd, the intensity of clinical attacks may be reduced significantly through selection and better management. Information on selection (particularly for cross-bred dairy cows in Bangladesh) of genetic characteristics related to individual resistance against mastitis and in establishing management of udder health control is a necessary prerequisite. Study on mastitis like morphological relationship of udder and teats with mastitis (Ahmed et al., 2005) have been carried out in Bangladesh. However, no comprehensive study to find out the prevalence of udder and teat diseases and their association with udder and teat characteristic, milk yield and milk flow rate in dairy cows has performed. Therefore, the present observational study in dairy cows was concerned with the objectives to study prevalence of udder and teat diseases in dairy cows, to study association of mastitis with udder and teat skin diseases and indices, and to study association of milk yield and milk flow rate with host characteristics.

${ }^{*}$ Corresponding author’s e-mail address: drasiruddin@gmail.com. 


\section{A. Uddin and others}

\section{MATERIALS AND METHODS}

\section{Study population and sampling}

The study was conducted during January 2008 to June 2009 on 581 dairy cows belonging to four Government establishments viz. Government Cattle Improvement and Dairy Farm, Rajabari, Rajshahi ( $\mathrm{n}=181$ ); Bangladesh Agricultural University Dairy Farm, Mymensingh ( $\mathrm{n}=28)$; Govt. Central Cattle Breeding Station and Dairy farm, Savar, Dhaka $(\mathrm{n}=323)$ and Sylhet Govt. Dairy farm, Tilagar, Sylhet $(\mathrm{n}=49)$. Both milch $479(82 \%)$ and dry 102 $(18 \%)$ cows were included in the study. Of the 581 dairy cows in this observational study most of them were high yielding indigenous cows and their crosses. There were 208 (35.8\%) indigenous cows, $163(28.1 \%)$ indigenous cross cows, 101 (17.1\%) Sahiwal and Sindhi cows, 45 (7.7\%) Jersey and Friesian cross cows and $64(11.0 \%)$ other breeds of cows. The herds were semi-intensively managed under experimental managerial system. Most of the cows were hand milked. High yielding cows were milked twice daily at 6-7 am and 4-5 pm. The data were collected in sketch cards (for ease of farmers) specifically designed for the purpose. The sketch cards were pretested prior to their final use.

\section{Explanatory variables}

Cow characteristics: Information on age and breed were collected from farm register. Body condition score was measured as suggested by Radostits and Blood (1985). Thickness of the skin at axilla was graded arbitrarily on the basis of digital palpation into thick, medium and thin.

Udder characteristics: Udder balance was judged on the basis of size of the quarters on inspection (Slettbakk et al., 1990). The size of the milk vein was classified arbitrarily into large, medium and small.

Teat characteristics: Teat characteristics were recorded after milking. The shape of the teat was classified according to description on Ovesen (1992) as follows: funnel, cylindrical and bottle. The teat end shape was classified as pointed, round and flat.

\section{Response variables}

Udder diseases: Sample of milk from each teat was collected separately and tested immediately for sub-clinical mastitis using modified Whiteside test (Rahman et al., 1997). Record of clinical mastitis was obtained mostly from patient register of the farms. Cases of clinical mastitis were also diagnosed on the cows individually (Nooruddin et al., 1997). Tick infestation and other udder skin diseases or lesions were diagnosed on the basis of physical finding of the lesions (Radostits et al., 1995) as recorded by close inspection.

Teat diseases and defects: The condition in which passage of milk and as a result, the process of milking was any way obstructed was diagnosed as teat stenosis (Roine, 1975). Teat papilloma was characterized by fron (warty, rough, filiform), and round and rice given types (Nooruddin et al., 1997). Teat injuries were characterized according to Rahman et al. (1997) by chapped fissure (cracked skin), acute hemorrhagic lesions and scars. Other teat diseases and defects were identified using physical characteristics of lesions.

Milk yield and milk flow rate: Information on milk yield was obtained from the farm record made annually and daily. Average daily milk yields in milch was calculated using daily milk yield for 16 day of the current lactation and total annual yield of the previous lactation. In dry cows daily average yield of previous lactation was used in the study. The procedure of obtaining dairy milk yield was described in the literature (Rogers and Spencer, 1991). Milk flow rate was obtained from milch cows only. Amount $(\mathrm{kg})$ of milk obtained per minute in the first 3 minutes of each milking was considered as milk flow rate.

\section{Study of association}

Statistical Packages for Social Sciences (SSPS) program was used in this study. Chi-square test was performed to have an idea about the association of cow, udder and teat characteristics with mastitis, udder skin and teat diseases (Everitt, 1992). Odds Ratio (OR) and adjusted odds ratio were studied for comparing the risk of developing different diseases. Adjusted odds ratio was estimated by Mantel-Haenszel Method (Schlesselman, 1982). Confidence limits for both the odds ratio and adjusted odds ratio were computed by using Woolf's method (Schlesselman, 1982). 


\section{RESULTS AND DISCUSSION}

\section{Prevalence of udder and teat diseases}

Mastitis $(26.0 \%)$ was the most common disease followed by udder skin diseases $(15.0 \%)$ and teat diseases $(12.6 \%)$. The prevalence of udder and teat diseases in dairy cows has presented in Table 1. Prevalence of the injuries and other lesions was higher in the skin of the fore left quarter of the udder $(22.7 \%)$ and teat $(17.7 \%)$ and rear left teat end (4.5\%). The prevalence of udder and teat skin and teat end indices (i.e. injuries and other lesions) has shown in Table 2.

Table 1. Prevalence of udder and teat diseases in dairy cows $(\mathrm{n}=581)$

\begin{tabular}{|l|l|l|}
\hline Diseases & No. of cases & Prevalence (\%) \\
\hline Subclinical mastitis & 122 & 21.0 \\
\hline Clinical mastitis & 29 & 5.0 \\
\hline Mastitis (subclinical and clinical) & 151 & 26.0 \\
\hline Udder skin diseases & 87 & 15.0 \\
\hline Udder tick infestation & 74 & 12.7 \\
\hline Teat injuries & 32 & 5.5 \\
\hline Teat papillioma & 26 & 4.5 \\
\hline Teat stenosis & 15 & 2.6 \\
\hline Teat diseases & 73 & 12.6 \\
\hline Congenital teat defects & 36 & 6.2 \\
\hline
\end{tabular}

$\mathrm{n}=$ number of cows examined.

Table 2. Prevalence of udder skin, teat skin and teat end indices (injury to the udder skin, teat skin and teat end) $(\mathrm{n}=581)$

\begin{tabular}{|c|c|c|c|c|c|c|c|c|c|}
\hline \multirow{2}{*}{$\begin{array}{l}\text { Degree of injury udder skin, teat skin } \\
\text { and teat end }\end{array}$} & \multirow[t]{2}{*}{ Score } & \multicolumn{2}{|l|}{ FR } & \multicolumn{2}{|l|}{ FL } & \multicolumn{2}{|l|}{ RR } & \multicolumn{2}{|l|}{ RL } \\
\hline & & $\begin{array}{l}\text { No } \\
\text { of } \\
\text { cases }\end{array}$ & $\%$ & $\begin{array}{l}\text { No } \\
\text { of } \\
\text { cases }\end{array}$ & $\%$ & $\begin{array}{l}\text { No } \\
\text { of } \\
\text { cases }\end{array}$ & $\%$ & $\begin{array}{l}\text { No } \\
\text { of } \\
\text { cases }\end{array}$ & $\%$ \\
\hline \multicolumn{10}{|l|}{ Udder Skin Indices } \\
\hline Healthy skin (no of injury) & 1 & 477 & 82.1 & 449 & 77.3 & 455 & 78.0 & 471 & 81.1 \\
\hline Cicatrices from healed skin lesions & 2 & 53 & 9.1 & 73 & 12.6 & 83 & 14.3 & 78 & 13.4 \\
\hline Superficial slight skin lesion & 3 & 44 & 7.6 & 50 & 8.6 & 34 & 5.9 & 22 & 3.8 \\
\hline Inflammation or deep lesion & 4 & 7 & 1.2 & 9 & 1.5 & 11 & 1.9 & 10 & 1.7 \\
\hline \multicolumn{10}{|l|}{ Teat Skin Indices } \\
\hline Healthy skin (no injury) & 1 & 466 & 80.2 & 478 & 82.3 & 503 & 86.6 & 535 & 92.1 \\
\hline Cicatrices from healed skin lesions & 2 & 81 & 13.9 & 72 & 12.4 & 41 & 7.1 & 16 & 2.8 \\
\hline Superficial slight skin lesion & 3 & 26 & 4.5 & 21 & 3.6 & 27 & 4.6 & 21 & 3.6 \\
\hline Inflammation or deep lesion & 4 & 8 & 1.4 & 10 & 1.7 & 10 & 1.7 & 9 & 1.5 \\
\hline \multicolumn{10}{|l|}{ Teat End Indices } \\
\hline Healthy skin (no injury) & 1 & 564 & 97.1 & 562 & 96.7 & 560 & 96.4 & 555 & 95.5 \\
\hline Cicatrices from healed skin lesions & 2 & 13 & 2.2 & 17 & 2.9 & 17 & 2.9 & 15 & 2.6 \\
\hline Superficial slight skin lesion & 3 & 1 & 0.2 & 0 & 0 & 0 & 0 & 2 & 0.3 \\
\hline Inflammation or deep lesion & 4 & 3 & 0.5 & 2 & 0.3 & 4 & 0.7 & 9 & 1.5 \\
\hline
\end{tabular}

$\mathrm{n}=$ Number of cows examined; FR $=$ Fore right teat, $\mathrm{FL}=$ Fore left teat; $\mathrm{RR}=$ Rear right teat, $\mathrm{RL}=$ Rear left teat. 


\section{A. Uddin and others}

The prevalence of subclinical $(21.0 \%)$ and clinical $(5.0 \%)$ mastitis (overall mastitis $26.0 \%)$ recorded in this study is different from that reported in exotic cows and their crosses from Bangladesh (Nooruddin et al., 1997; Rahman et al., 1997) and other countries (Oltenacu et al., 1990). The prevalence of teat papillomastitis (4.5\%) and teat injuries $(5.5 \%)$ recorded currently is also not similar to that reported in exotic cows and their crosses from Bangladesh (Nooruddin et al., 1997; Rahman et al., 1997) and abroad (Saloniemi, 1980). The prevalence of teat stenosis (2.6\%) of this study is much lower than that (46.2\%) reported in exotic cows of Finland by Ronie (1975). Prevalence of injuries and lesions in the skin of udder and teat, teat defects is much higher than that (0.6-1.4\%) reported from Finland by Saloniemi (1980). Saloniemi (1980) reported 25-29\% of teat end injuries which is much higher than that of the present record of $4.5 \%$. The variation in prevalence of udder and teat diseases between the present previous studies might due to differences in genetic composition of the study cows, their management and geo-climatic conditions in the location of studies.

\section{Association of udder and teat diseases with udder and teat characteristic}

Mastitis (subclinical and clinical overall) was found to be associated with Sahiwal and Sindhi cross cows (Odd Ratio-OR 1.92), poor condition of the animal (OR 2.26), bottle shaped teat (OR 1.84) and teat with round end (OR 1.67). Subclinical mastitis was related with many characteristics of the cows, but a strong association was observed with cows aged over 10 years (OR 2.00), poor condition (OR 2.83), small sized milk vein (OR 5.89) and botttle shaped teats (OR 2.34). The distribution and association of mastitis with cow, udder and teat characteristics have shown in Table 3. In other studies mastitis was reported to be associated with older cows and with poor condition (Gearhart and Curtis, 1990; Faye et al. 1998), bottle shape teat (Sutradhar, 1999), funnnel shaped teat (Shukla et al. 1997), pencil from teat (Rahman et al., 1986), conical teat (Ruban et al., 1993), cylindrical teats and inverted teat end. Variable result or no relation of mastitis with teat shape was obtained by Wittorff et al. (1987). The difference in the composition of breeds of study cows might be responsible for the variation in the results of present and previous studies.

The udder skin and teat diseases were found to be strongly associated with indigenous cows, cows aged 5-10 years, small sized milk vein, larger front udder, bottle shaped teats and flat end teats. Teat diseases (stenosis, papilloma, injuries) and defects were not found to be associated with any of cow, udder and teat characteristics on statistical analysis $(\mathrm{P}>0.05)$. The distribution and association relationship of udder skin diseases (overall) and udder tick infestation with host characteristics are presented in Table 4 . The present finding of the association of mastitis with teat diseases and injuries and lesions in the skin of udder, teat and teat ends confirm the previous observations of Saloniemi (1980) and Radostits et al. (1995). Saloniemi (1980) reported a significant positive correlation between very slight skin injuries in the teat and the occurrence of subclinical mastitis, although mumber of teat injuries in the herds troubled by mastitis did not always exceed the average. Teat injuries provide a medium for the growth of the pathogenic bacteria which affect the udder, so that in the case of injuries the risk of an infection increases (Saloniemi, 1980). Pointed teat was susceptible to erosion (Bakken, 1981). Mastitis was found to be associated with skin injuries and lesions in the rear left quarter of the udder (odds ratio-OR 1.64) and teat skin and teat end lesions. Association of mastitis with injuries and other lesions in the udder and teats has been described in Table 5. Udder skin diseases were found to be associated with local cows, 5-10 years old cows, thin skin and larger front udder. Udder tick infestation resulted in the higher prevalence of udder skin diseases particularly in the Rajshahi dairy farm which maintained only the high yielding indigenous cattle. The hot humid of the geographic location might be responsible for prevalence of udder skin diseases in the present study.

\section{Milk yield and milk flow rate}

Higher milk yield was observed in Sahiwal and Sindhi cross cows and younger cows aged $\leq 5$ years. Milk flow rate was significantly higher in Sahiwal and Sindhi cross cows, large milk vein, greater front udder, funnel and cylindrical teats and pointed teats. The distribution and association of milk yield and milk flow rate with cow udder and teat characteristics have been presented in Table 6. Higher milk yield was recorded in Sahiwal and Sindhi cross cows, and younger cows ages $\leq 5$ years. No relationship of milk yield with body condition, skin thickness, milk vein size, udder balance and teat end shape was observed in this study. These findings partially confirm the previous observation of Rogers and Spencer (1991) who reported non-significant differences in the level of milk production in different teat shapes. However, higher milk yield was recorded in cows with funnel shape testes (Sutradhar, 1999), pear shaped teats, bottle shaped teats (Rahman et al., 1986) and cylindrical teats (Islam, 1999). The differences in the result of the studies might me attributable to differences in the genetic composition of study cows. 
Milk flow rate was found to be associated with large milk vein, larger front udder, funnel and cylindrical teats with pointed ends. Higher milk flow rate was reported in cows with larger teat diameter, inverted teat and saucer shape teats, although no relation of milk flow rate was found with teat tip shape and udder diseases (Dobicki et al., 1980). Differences in genetic composition of dairy cows between the studies might responsible for differences in the observations in milk flow rate. The present study included most of the local dairy cows.

Table 3. Distribution and association of mastitis (sub-clinical and clinical) with cow, udder and teat characteristics

\begin{tabular}{|c|c|c|c|c|c|c|c|c|}
\hline \multicolumn{2}{|l|}{ Variables } & \multirow{2}{*}{$\begin{array}{l}\text { No. } \\
\text { of } \\
\text { cows }\end{array}$} & \multirow{2}{*}{$\begin{array}{l}\text { No. } \\
\text { of } \\
\text { cases }\end{array}$} & \multirow{2}{*}{$\begin{array}{l}\text { Prevalence } \\
(\%)\end{array}$} & \multirow{2}{*}{\begin{tabular}{|l} 
Chi- \\
square \\
value
\end{tabular}} & \multirow{2}{*}{$\begin{array}{l}\text { Odd } \\
\text { ratio } \\
(\Psi)\end{array}$} & \multirow{2}{*}{$\begin{array}{l}95 \% \\
\text { confidence } \\
\text { limits }\end{array}$} & \multirow{2}{*}{$\begin{array}{l}\text { Mantel } \\
\text { haenszel's } \\
\text { chisquare value }\end{array}$} \\
\hline Name & Categories & & & & & & & \\
\hline Breed & $\begin{array}{l}\text { Local } \\
\text { Local cross } \\
\text { Sahiwal-Sindhi cross } \\
\text { Others }\end{array}$ & $\begin{array}{l}208 \\
163 \\
101 \\
109\end{array}$ & $\begin{array}{l}58 \\
31 \\
38 \\
24 \\
\end{array}$ & $\begin{array}{l}27.88 \\
19.02 \\
37.62 \\
22.02 \\
\end{array}$ & $12.507 * *$ & $\begin{array}{l}1.16 \\
0.58 \\
1.96^{*} \\
0.77\end{array}$ & \begin{tabular}{|l|}
$(0.79,1.70)$ \\
$(0.37,0.90)$ \\
$(1.24,3.09)$ \\
$(0.47,1.27)$ \\
\end{tabular} & $\begin{array}{l}- \\
- \\
- \\
-\end{array}$ \\
\hline Age & $\begin{array}{l}\leq 5 \text { years } \\
5-10 \text { years } \\
>10 \text { years }\end{array}$ & $\begin{array}{l}168 \\
351 \\
62 \\
\end{array}$ & $\begin{array}{l}41 \\
87 \\
23 \\
\end{array}$ & \begin{tabular}{|l|}
24.40 \\
24.79 \\
37.10 \\
\end{tabular} & 4.460 & $\begin{array}{l}0.89 \\
0.85 \\
1.80 \\
\end{array}$ & $\begin{array}{l}(0.58,1.34) \\
(0.60,1.29) \\
(0.98,3.00)\end{array}$ & $\begin{array}{l}- \\
- \\
-\end{array}$ \\
\hline $\begin{array}{l}\text { Body } \\
\text { condition } \\
\text { score }\end{array}$ & $\begin{array}{l}\text { Poor } \\
\text { Light moderate } \\
\text { Moderate } \\
\text { Fat } \\
\end{array}$ & \begin{tabular}{|l|}
38 \\
125 \\
295 \\
123 \\
\end{tabular} & $\begin{array}{l}17 \\
42 \\
66 \\
26 \\
\end{array}$ & \begin{tabular}{|l|}
44.74 \\
33.60 \\
22.37 \\
21.10 \\
\end{tabular} & $14.220 * *$ & $\begin{array}{l}2.16^{*(a b)} \\
1.59^{(a b)} \\
0.73^{(a b)} \\
0.70^{(a b)} \\
\end{array}$ & \begin{tabular}{|l|}
$(1.02,4.60)$ \\
$(1.02,2.46)$ \\
$(0.50,1.07)$ \\
$(0.42,1.19)$ \\
\end{tabular} & \begin{tabular}{|l|}
$4.023^{*}$ \\
3.801 \\
2.216 \\
1.753 \\
\end{tabular} \\
\hline $\begin{array}{l}\text { Skin } \\
\text { thickness }\end{array}$ & \begin{tabular}{|l|} 
Thick \\
Medium \\
Thin \\
\end{tabular} & $\begin{array}{l}311 \\
216 \\
54 \\
\end{array}$ & $\begin{array}{l}82 \\
53 \\
16 \\
\end{array}$ & $\begin{array}{l}26.37 \\
24.54 \\
29.63 \\
\end{array}$ & 0.632 & $\begin{array}{l}1.04 \\
0.89 \\
0.74 \\
\end{array}$ & $\begin{array}{l}(0.73,1.54) \\
(0.60,1.31) \\
(0.46,1.20) \\
\end{array}$ & $\begin{array}{l}- \\
- \\
-\end{array}$ \\
\hline $\begin{array}{l}\text { Milk vein } \\
\text { size }\end{array}$ & \begin{tabular}{|l} 
Large \\
medium \\
small \\
\end{tabular} & $\begin{array}{l}331 \\
175 \\
75 \\
\end{array}$ & $\begin{array}{l}80 \\
47 \\
24 \\
\end{array}$ & $\begin{array}{l}24.17 \\
26.86 \\
32.00 \\
\end{array}$ & 2.047 & $\begin{array}{l}0.82 \\
1.01 \\
1.45 \\
\end{array}$ & $\begin{array}{c}(0.56,1.19) \\
(0.67,1.52) \\
(0.86,2.45) \\
\end{array}$ & $\begin{array}{l}- \\
- \\
- \\
\end{array}$ \\
\hline $\begin{array}{l}\text { Udder } \\
\text { balance }\end{array}$ & $\begin{array}{l}\text { Front udder }>>\text { rear } \\
\text { Front udder }>\text { rear } \\
\text { Symmetric } \\
\text { Front udder }<\text { rear } \\
\text { Front udder }<<\text { rear }\end{array}$ & $\begin{array}{l}170 \\
184 \\
154 \\
67 \\
6 \\
\end{array}$ & $\begin{array}{l}52 \\
44 \\
42 \\
11 \\
2 \\
\end{array}$ & \begin{tabular}{|l|}
30.59 \\
23.90 \\
27.27 \\
16.40 \\
33.30 \\
\end{tabular} & 5.773 & $\begin{array}{l}1.33 \\
0.89 \\
1.08 \\
0.54 \\
1.47 \\
\end{array}$ & \begin{tabular}{|l}
$(0.89,1.98)$ \\
$(0.59,1.34)$ \\
$(0.71,164)$ \\
$(0.27,1.06)$ \\
$(0.27,8.11)$ \\
\end{tabular} & $\begin{array}{l}- \\
- \\
- \\
- \\
-\end{array}$ \\
\hline $\begin{array}{l}\text { Teat shape } \\
\text { (front teats) }\end{array}$ & $\begin{array}{l}\text { Funnel } \\
\text { Cylindrical } \\
\text { Bottle } \\
\end{array}$ & $\begin{array}{l}390 \\
123 \\
68 \\
\end{array}$ & $\begin{array}{l}90 \\
36 \\
25 \\
\end{array}$ & \begin{tabular}{|l|}
23.08 \\
29.27 \\
36.80 \\
\end{tabular} & 6.512* & $\begin{array}{l}0.69^{(\mathrm{ab})} \\
1.23^{(\mathrm{ab})} \\
1.80^{(\mathrm{ab})} \\
\end{array}$ & $\begin{array}{l}(0.46,1.03) \\
(0.69,1.85) \\
(1.01,3.22) \\
\end{array}$ & $\begin{array}{l}3.153 \\
0.179 \\
3.538 \\
\end{array}$ \\
\hline $\begin{array}{l}\text { Teat shape } \\
\text { (rear teats) }\end{array}$ & $\begin{array}{l}\text { Funnel } \\
\text { Cylindrical } \\
\text { Bottle }\end{array}$ & $\begin{array}{l}432 \\
105 \\
44 \\
\end{array}$ & $\begin{array}{l}102 \\
33 \\
16 \\
\end{array}$ & \begin{tabular}{|l|}
23.61 \\
31.4 \\
36.4 \\
\end{tabular} & 5.347 & $\begin{array}{l}0.60 \\
1.43 \\
1.75 \\
\end{array}$ & $\begin{array}{l}(0.40,0.90) \\
(0.90,2.27) \\
(0.91,3.34) \\
\end{array}$ & $\begin{array}{l}- \\
- \\
- \\
\end{array}$ \\
\hline \begin{tabular}{|l|} 
Teat end \\
shape \\
(front teats) \\
\end{tabular} & $\begin{array}{l}\text { Pointed } \\
\text { Round } \\
\text { Flat } \\
\end{array}$ & $\begin{array}{l}402 \\
137 \\
42 \\
\end{array}$ & $\begin{array}{l}97 \\
43 \\
11 \\
\end{array}$ & \begin{tabular}{|l|}
24.13 \\
31.40 \\
26.19 \\
\end{tabular} & 2.799 & $\begin{array}{l}0.68^{(a b)} \\
1.59^{(a b)} \\
0.90^{(a b)}\end{array}$ & $\begin{array}{l}(0.46,1.00) \\
(1.05,2.43) \\
(0.07,11.65) \\
\end{array}$ & $\begin{array}{l}3.479 \\
4.598 * \\
0.006 \\
\end{array}$ \\
\hline \begin{tabular}{|l}
$\begin{array}{l}\text { Teat end } \\
\text { shape } \\
\text { (rear teats) }\end{array}$ \\
\end{tabular} & $\begin{array}{l}\text { Pointed } \\
\text { Round } \\
\text { Flat }\end{array}$ & $\begin{array}{l}393 \\
148 \\
40 \\
\end{array}$ & $\begin{array}{l}91 \\
50 \\
10 \\
\end{array}$ & \begin{tabular}{|l|}
23.16 \\
33.78 \\
25.00 \\
\end{tabular} & $6.336^{*}$ & $\begin{array}{l}0.68^{(a b)} \\
1.59^{*(a b)} \\
0.90^{(a b)}\end{array}$ & $\begin{array}{l}(0.46,1.00) \\
(1.05,2.43) \\
(0.07,11.65) \\
\end{array}$ & $\begin{array}{l}3.479 \\
4.598 * \\
0.006 \\
\end{array}$ \\
\hline
\end{tabular}

*means significant at $5 \%$ level (p value $<0.05)$, **means significant at $1 \%$ level (p value $<0.01)$ and $(a b)$ indicates adjusted for breed. 


\section{A. Uddin and others}

Table 4. Distribution and association of udder skin diseases with cow, udder and teat characteristics

\begin{tabular}{|c|c|c|c|c|c|c|c|}
\hline \multicolumn{2}{|l|}{ Variables } & \multirow{2}{*}{$\begin{array}{l}\text { No. of } \\
\text { cows }\end{array}$} & \multirow{2}{*}{$\begin{array}{l}\text { No. of } \\
\text { cows }\end{array}$} & \multirow{2}{*}{$\begin{array}{l}\text { Prevalence } \\
(\%)\end{array}$} & \multirow{2}{*}{$\begin{array}{l}\text { Chi-square } \\
\text { value }\end{array}$} & \multirow{2}{*}{$\begin{array}{l}\text { Odd } \\
\operatorname{ratio}(\Psi)\end{array}$} & \multirow{2}{*}{$\begin{array}{l}95 \% \text { confidence } \\
\text { limits }\end{array}$} \\
\hline Name & Categories & & & & & & \\
\hline Breed & $\begin{array}{l}\text { Local } \\
\text { Local cross } \\
\text { Sahiwals-Sindhi cross } \\
\text { Others }\end{array}$ & $\begin{array}{l}208 \\
163 \\
101 \\
109 \\
\end{array}$ & $\begin{array}{l}67 \\
8 \\
7 \\
5 \\
\end{array}$ & $\begin{array}{l}32.21 \\
4.91 \\
6.93 \\
4.59 \\
\end{array}$ & $75.883 * *$ & $\begin{array}{l}8.39 * \\
0.22 \\
0.37 \\
0.23 \\
\end{array}$ & \begin{tabular}{|l|}
$(4.91,14.34)$ \\
$(0.10,0.47)$ \\
$(0.17,0.83)$ \\
$(0.00,0.58)$ \\
\end{tabular} \\
\hline Age & $\begin{array}{l}\leq 5 \text { years } \\
5-10 \text { years } \\
>10 \text { years }\end{array}$ & $\begin{array}{l}168 \\
351 \\
62 \\
\end{array}$ & \begin{tabular}{|l|}
5 \\
70 \\
12 \\
\end{tabular} & \begin{tabular}{|l|}
2.98 \\
19.94 \\
19.35 \\
\end{tabular} & $26.736 * *$ & \begin{tabular}{|l|}
0.12 \\
$3.12 *$ \\
1.42 \\
\end{tabular} & $\begin{array}{l}(0.05,0.30) \\
(1.78,5.46) \\
(0.72,2.79) \\
\end{array}$ \\
\hline $\begin{array}{l}\text { Body } \\
\text { Condition } \\
\text { score }\end{array}$ & $\begin{array}{l}\text { Poor } \\
\text { Light moderate } \\
\text { Moderate } \\
\text { Fat }\end{array}$ & \begin{tabular}{|l|}
38 \\
125 \\
295 \\
123 \\
\end{tabular} & $\begin{array}{l}3 \\
22 \\
40 \\
22 \\
\end{array}$ & \begin{tabular}{|l|}
7.89 \\
17.60 \\
13.56 \\
17.89 \\
\end{tabular} & 3.456 & $\begin{array}{l}0.47 \\
1.28 \\
0.78 \\
1.32 \\
\end{array}$ & \begin{tabular}{|l|}
$(0.51,1.63)$ \\
$(0.75,2.17)$ \\
$(0.49,1.23)$ \\
$(0.78,2.24)$ \\
\end{tabular} \\
\hline $\begin{array}{l}\text { Skin } \\
\text { thickness }\end{array}$ & $\begin{array}{l}\text { Thick } \\
\text { Medium } \\
\text { Thin } \\
\end{array}$ & \begin{tabular}{|l|}
331 \\
216 \\
54 \\
\end{tabular} & \begin{tabular}{|l|}
34 \\
36 \\
17 \\
\end{tabular} & \begin{tabular}{|l|}
10.93 \\
16.67 \\
13.48 \\
\end{tabular} & $16.033 * *$ & $\begin{array}{l}0.50 \\
1.23 \\
3.00 * \\
\end{array}$ & $\begin{array}{l}(0.31, .80) \\
(0.77,1.96) \\
(1.60,52.30) \\
\end{array}$ \\
\hline $\begin{array}{l}\text { Milk vein } \\
\text { size }\end{array}$ & $\begin{array}{l}\text { Large } \\
\text { Medium } \\
\text { Small } \\
\end{array}$ & $\begin{array}{l}331 \\
175 \\
75 \\
\end{array}$ & $\begin{array}{l}37 \\
32 \\
18 \\
\end{array}$ & \begin{tabular}{|l|}
11.18 \\
18.29 \\
24.00 \\
\end{tabular} & $10.052 * *$ & $\begin{array}{l}0.50 \\
1.43 \\
2.00^{*} \\
\end{array}$ & $\begin{array}{l}(0.32,0.79) \\
(0.89,2.30) \\
(1.11,3.60) \\
\end{array}$ \\
\hline $\begin{array}{l}\text { Udder } \\
\text { Balance }\end{array}$ & $\begin{array}{l}\text { Frontudder }>>\text { rear } \\
\text { Front udder }>>\text { rear } \\
\text { Symmetric } \\
\text { Frontudder }<\text { rear } \\
\text { Front udder }<<\text { rear }\end{array}$ & $\begin{array}{l}170 \\
184 \\
154 \\
67 \\
6 \\
\end{array}$ & $\begin{array}{l}57 \\
10 \\
18 \\
2 \\
0 \\
\end{array}$ & \begin{tabular}{|l|}
33.53 \\
5.43 \\
11.69 \\
2.99 \\
0.00 \\
\end{tabular} & $69.049 * *$ & $\begin{array}{l}6.41^{*} \\
0.24 \\
0.69 \\
0.16 \\
0.00 \\
\end{array}$ & $\begin{array}{l}(3.93,10.46) \\
(0.12,0.48) \\
(0.40,1.20) \\
(0.04,0.67) \\
- \\
\end{array}$ \\
\hline $\begin{array}{l}\text { Teat shape } \\
\text { (front teats) }\end{array}$ & $\begin{array}{l}\text { Funnel } \\
\text { Cylindrical } \\
\text { Bottle } \\
\end{array}$ & \begin{tabular}{|l|}
390 \\
123 \\
68 \\
\end{tabular} & \begin{tabular}{|l|}
68 \\
30 \\
24 \\
\end{tabular} & \begin{tabular}{|l|}
17.43 \\
24.39 \\
35.29 \\
\end{tabular} & $12.21^{*}$ & $\begin{array}{l}0.62^{(\mathrm{ab})} \\
1.13^{(\mathrm{ab})} \\
2.12^{(\mathrm{ab})} \\
\end{array}$ & $\begin{array}{l}(0.41,0.95) \\
(0.66,1.94) \\
(1.19,3.77) \\
\end{array}$ \\
\hline $\begin{array}{l}\text { Teat shape } \\
\text { (rear teats) }\end{array}$ & $\begin{array}{l}\text { Funnel } \\
\text { Cylindrical } \\
\text { Bottle }\end{array}$ & $\begin{array}{l}432 \\
105 \\
44 \\
\end{array}$ & \begin{tabular}{|l|}
77 \\
29 \\
16 \\
\end{tabular} & \begin{tabular}{|l|}
17.82 \\
27.62 \\
36.36 \\
\end{tabular} & $11.66^{*}$ & $\begin{array}{l}0.56^{(\mathrm{ab})} \\
1.56^{(\mathrm{ab})} \\
1.82^{(\mathrm{ab})}\end{array}$ & $\begin{array}{l}(0.36,0.86) \\
(0.94,2.59) \\
(0.90,3.03)\end{array}$ \\
\hline $\begin{array}{l}\text { Teat end } \\
\text { Shape } \\
\text { (front teats) }\end{array}$ & $\begin{array}{l}\text { Pointed } \\
\text { Round } \\
\text { Flat }\end{array}$ & $\begin{array}{l}402 \\
137 \\
42\end{array}$ & $\begin{array}{l}73 \\
39 \\
10\end{array}$ & $\begin{array}{l}18.16 \\
28.47 \\
23.81\end{array}$ & $6.76^{*}$ & $\begin{array}{l}0.68^{(\mathrm{ab})} \\
1.60^{(\mathrm{ab})} \\
0.93^{(\mathrm{ab})}\end{array}$ & $\begin{array}{l}(0.44,1.03) \\
(1.02,2.52) \\
(0.00,247656.47)\end{array}$ \\
\hline $\begin{array}{l}\text { Teat end } \\
\text { Shape } \\
\text { (rear teats) }\end{array}$ & $\begin{array}{l}\text { Pointed } \\
\text { Round } \\
\text { Flat }\end{array}$ & \begin{tabular}{|l|}
393 \\
148 \\
40 \\
\end{tabular} & \begin{tabular}{|l|}
69 \\
43 \\
10 \\
\end{tabular} & $\begin{array}{l}17.56 \\
29.05 \\
25.00 \\
\end{array}$ & 8.98* & $\begin{array}{l}0.60^{(\mathrm{ab})} \\
1.72^{(\mathrm{ab})} \\
1.09^{(\mathrm{ab})}\end{array}$ & $\begin{array}{l}(0.39,0.91) \\
(1.10,2.70) \\
(0.01,169.36) \\
\end{array}$ \\
\hline
\end{tabular}

*means significant at $5 \%$ level ( $\mathrm{p}$ value $<0.05)$, **means significant at $1 \%$ level (p value $<0.01)$. 
Udder and teat diseases in dairy cows

Table 5. Distribution and association of mastitis (sub-clinical and clinical) with udder skin indices, teat skin indices and teat end indices

\begin{tabular}{|c|c|c|c|c|c|c|c|}
\hline \multicolumn{2}{|l|}{ Variables } & \multirow{2}{*}{$\begin{array}{l}\text { No. of } \\
\text { Cows }\end{array}$} & \multirow{2}{*}{$\begin{array}{l}\text { No. of } \\
\text { cases }\end{array}$} & \multirow{2}{*}{$\begin{array}{l}\text { Prevalence } \\
(\%)\end{array}$} & \multirow{2}{*}{$\begin{array}{l}\text { Chi- square } \\
\text { value }\end{array}$} & \multirow{2}{*}{$\begin{array}{l}\text { Odds } \\
\text { Ratio }\end{array}$} & \multirow{2}{*}{$\begin{array}{l}95 \% \\
\text { Confidence } \\
\text { limits }\end{array}$} \\
\hline Name & Categories & & & & & & \\
\hline \multicolumn{8}{|l|}{ Injury to Udder Skin } \\
\hline \multirow[t]{2}{*}{ Fore right quarter (fr) } & Healthy & 477 & 111 & 23.3 & \multirow{2}{*}{$6.812 * *$} & 0.55 & $0.35,0.87$ \\
\hline & Lesion & 104 & 37 & 35.6 & & 0.55 & $0.35,0.87$ \\
\hline \multirow[t]{2}{*}{ Fore left quarter (fl) } & Healthy & 449 & 109 & 24.3 & \multirow{2}{*}{1.492} & 0.76 & $0.49,1.17$ \\
\hline & Lesion & 132 & 39 & 29.5 & & 1.31 & $0.85,2.02$ \\
\hline \multirow[t]{2}{*}{ Rear right quarter (fr) } & Healthy & 453 & 107 & 23.6 & \multirow{2}{*}{$3.719^{*}$} & 0.66 & $0.43,1.01$ \\
\hline & Lesion & 128 & 41 & 32.0 & & 1.52 & $0.99,2.34$ \\
\hline \multirow[t]{2}{*}{ Rear left quarter (rt) } & Healthy & 471 & 111 & 23.6 & \multirow{2}{*}{$4.763 *$} & 0.61 & $0.39,0.96$ \\
\hline & Lesion & 110 & 37 & 33.6 & & $1.64 *$ & $1.05,2.57$ \\
\hline \multicolumn{8}{|l|}{ Injury to Teat Skin } \\
\hline \multirow[t]{2}{*}{ Fore right quarter (fr) } & Healthy & 466 & 109 & 23.4 & \multirow[t]{2}{*}{$5.38^{*}$} & 0.59 & $0.38,0.92$ \\
\hline & Lesion & 115 & 39 & 33.9 & & $1.68^{*}$ & $1.08,2.61$ \\
\hline \multirow[t]{2}{*}{ Fore left quarter (fl) } & Healthy & 478 & 106 & 22.9 & \multirow[t]{2}{*}{$15.444 * *$} & 0.41 & $0.26,0.64$ \\
\hline & Lesion & 103 & 42 & 40.8 & & $2.42 *$ & $1.55,3.79$ \\
\hline \multirow[t]{2}{*}{ Rear right quarter (rr) } & Healthy & 503 & 127 & 25.2 & \multirow[t]{2}{*}{0.100} & 0.92 & $0.54,1.58$ \\
\hline & Lesion & 78 & 21 & 26.9 & & $1.90^{*}$ & $1.11,3.26$ \\
\hline \multirow[t]{2}{*}{ Rear left quarter (rt) } & Healthy & 535 & 131 & 24.5 & \multirow[t]{2}{*}{$3.470^{*}$} & 0.55 & $0.29,3.26$ \\
\hline & Lesion & 46 & 17 & 37.6 & & 1.81 & $0.96,3.40$ \\
\hline \multicolumn{8}{|l|}{ Injury to Teat End } \\
\hline \multirow[t]{2}{*}{ Fore right quarter (fr) } & Healthy & 564 & 139 & 24.6 & \multirow[t]{2}{*}{$6.960 * *$} & 0.29 & $0.11,0.77$ \\
\hline & Lesion & 17 & 9 & 52.9 & & $3.44 *$ & $1.30,9.09$ \\
\hline \multirow[t]{2}{*}{ Fore left quarter (fl) } & Healthy & 562 & 137 & 24.4 & \multirow[t]{2}{*}{$10.876^{*}$} & 0.23 & $0.09,0.58$ \\
\hline & Lesion & 19 & 11 & 57.9 & & 4.27 & $1.68,10.83$ \\
\hline \multirow[t]{2}{*}{ Rear right quarter (rr) } & Healthy & 560 & 138 & 24.6 & $5.628 *$ & 0.36 & $0.15,0.87$ \\
\hline & Lesion & 21 & 10 & 47.6 & & 2.78 & $1.16,6.69$ \\
\hline Rear left quarter (rt) & Healthy & 555 & 134 & 24.1 & $11.542 * *$ & 0.27 & $0.12,0.60$ \\
\hline & Lesion & 26 & 14 & $11.542 * *$ & & $3.67 *$ & $1.66,8.13$ \\
\hline
\end{tabular}

* Significant at $5 \%$ level; **significant at $1 \%$ level. 


\section{A. Uddin and others}

Table 6. Distribution and association of milk yield with cow, udder and teat characteristics

\begin{tabular}{|c|c|c|c|c|}
\hline \multicolumn{2}{|l|}{ variables } & \multirow{2}{*}{ No. of cows } & \multirow{2}{*}{ Mean \pm sd } & \multirow{2}{*}{ F-value } \\
\hline Name & Categories & & & \\
\hline Breed & $\begin{array}{l}\text { Local } \\
\text { Local cross } \\
\text { Sahiwal and Sindhi cross } \\
\text { Others }\end{array}$ & $\begin{array}{l}208 \\
163 \\
101 \\
29\end{array}$ & $\begin{array}{l}3.05 \pm 1.14 \\
4.67 \pm 1.95 \\
5.07 \pm 2.65 \\
4.43 \pm 2.39\end{array}$ & $1.620 * *$ \\
\hline Age & $\begin{array}{l}\leq 5 \text { years } \\
5-10 \text { years } \\
>10 \text { years }\end{array}$ & $\begin{array}{l}168 \\
351 \\
62\end{array}$ & $\begin{array}{l}4.45 \pm 1.71 \\
4.01 \pm 2.21\end{array}$ & $1.604 * *$ \\
\hline $\begin{array}{l}\text { Body } \\
\text { Condition } \\
\text { score }\end{array}$ & $\begin{array}{l}\text { Poor } \\
\text { Light moderate } \\
\text { Moderate } \\
\text { Fat }\end{array}$ & $\begin{array}{l}38 \\
125 \\
295 \\
123\end{array}$ & $\begin{array}{l}4.38 \pm 1.42 \\
3.24 \pm 1.08 \\
4.12 \pm 1.94 \\
4.95 \pm 2.85\end{array}$ & 0.660 \\
\hline Skin thickness & $\begin{array}{l}\text { Thick } \\
\text { medium } \\
\text { Thin }\end{array}$ & $\begin{array}{l}311 \\
216 \\
54\end{array}$ & $\begin{array}{l}4.43 \pm 2.29 \\
3.87 \pm 1.79 \\
3.36 \pm 1.39\end{array}$ & 0.857 \\
\hline Milk vein size & $\begin{array}{l}\text { Large } \\
\text { medium } \\
\text { Small }\end{array}$ & $\begin{array}{l}331 \\
175 \\
75\end{array}$ & $\begin{array}{l}4.45 \pm 2.19 \\
3.91 \pm 2.01 \\
3.19 \pm 1.16\end{array}$ & 0.882 \\
\hline $\begin{array}{l}\text { Udder } \\
\text { Balance }\end{array}$ & $\begin{array}{l}\text { Front udder }>>\text { rear } \\
\text { Front udder }>>\text { rear } \\
\text { Symmetric } \\
\text { Front udder }<\text { rea } \\
\text { Front udder }<<\text { rear }\end{array}$ & $\begin{array}{l}170 \\
184 \\
154 \\
67 \\
6\end{array}$ & $\begin{array}{l}3.39 \pm 1.47 \\
4.39 \pm 2.20 \\
4.15 \pm 1.92 \\
5.15 \pm 2.72 \\
4.28 \pm 0.53\end{array}$ & 0.666 \\
\hline $\begin{array}{l}\text { Teat shape } \\
\text { (front teats }\end{array}$ & $\begin{array}{l}\text { Funnel } \\
\text { Cylindrical } \\
\text { Bottle }\end{array}$ & $\begin{array}{l}390 \\
123 \\
68\end{array}$ & $\begin{array}{l}4.43 \pm 2.24 \\
3.63 \pm 1.73 \\
3.28 \pm 0.95\end{array}$ & 0.696 \\
\hline $\begin{array}{l}\text { Teat shape } \\
\text { (rear teats) }\end{array}$ & $\begin{array}{l}\text { Funnel } \\
\text { Cylindrical } \\
\text { Bottle }\end{array}$ & $\begin{array}{l}432 \\
105 \\
44\end{array}$ & $\begin{array}{l}4.27 \pm 2.19 \\
3.91 \pm 1.76 \\
3.21 \pm 1.18\end{array}$ & 0.601 \\
\hline $\begin{array}{l}\text { Teat end } \\
\text { Shape } \\
\text { (front teats) }\end{array}$ & $\begin{array}{l}\text { Pointed } \\
\text { Round } \\
\text { Flat }\end{array}$ & $\begin{array}{l}402 \\
137 \\
42\end{array}$ & $\begin{array}{l}4.32 \pm 2.16 \\
3.76 \pm 1.88 \\
3.40 \pm 1.54\end{array}$ & 0.764 \\
\hline $\begin{array}{l}\text { Teat end } \\
\text { Shape } \\
\text { (rear teats) }\end{array}$ & $\begin{array}{l}\text { Pointed } \\
\text { Round } \\
\text { Flat }\end{array}$ & $\begin{array}{l}393 \\
148 \\
40\end{array}$ & $\begin{array}{l}4.27 \pm 2.20 \\
3.90 \pm 1.78 \\
3.40 \pm 1.54\end{array}$ & 0.633 \\
\hline
\end{tabular}

*significant at $5 \%$ level; ** significant at $1 \%$ level.

The author hopes that the findings of this study will be fruitful for scientific community as well for dairy farmers in Bangladesh. The prevalence of udder and teat diseases in dairy cows in Bangladesh is high. The relationship of udder and teat diseases as well as udder and teat characteristics varies with the genetic composition of the dairy cows. Therefore, further genomic study needs to confirm association of udder and teat diseases with host characteristics. 


\section{REFERENCES}

1. Ahmed JU, Sutradhar S and Rahman MM (2005). Morphological characteristics of udders and teats in relation to mastitis and milk yield in crossbred dairy cows. The Bangladesh Veterinarian 22: 23-28.

2. Bakken G (1981). Relationship between udder and teat morphology, mastitis and milk production in Norwegian Red Cattle. Acta Agriculturae Scandinavica 31: 439-444.

3. BBS (2004). Yearbook of Agricultural Statistics of Bangladesh. Bangladesh Bureau of Statistics. Government of the People's Republic of Bangladesh pp: 253.

4. Dobicki A, Juszczak J, Marcinkowski K and Szulc T (1980). Udder health in relation to some udder structure characteristics and milkability of cows. Medycyna Weterrynaryjan 36: 107-110.

5. Everitt BS (1992). The analysis of contingency tables. Chapman \& Hall, London, pp. 6-10.

6. Faye B, Perochon L, Dorr N and Gasqui P (1998). Relationship between individual- cow udder health status in early lactation and dairy cow characteristic in Brittany, France. Veterinary Research 29: 31-46.

7. Gearhart MA and Curtis CR (1990). Relationship of changes in condition score to cow health in Holsteins. Journal of Dairy Science 73: 3132-3140.

8. Islam MR (1999). Importance of udder characteristics in selecting crossbred dairy cows on milk yield. MS Thesis, Department of Dairy Science, Faculty of Animal Husbandry, Bangladesh Agricultural University, Mymensingh. pp. 65.

9. Kivaria FM, Noordhuizen JPTM and Kapaga AM (2004). Risk factors associated with sub-clinical mastitis in smallholder dairy cows in Tanzania. Tropical Animal Health and Production 36: 581-592.

10. Nooruddin M, Rahman MS and Rahman MM (1997). Prevalence and distribution of teat papillomatosis in crossbred and exotic dairy cows. The Bangladesh Veterinarian 14: 5-7.

11. Oltenacu PA, Frick A and Lindhe B (1990). Epidemiological study of several clinical diseases, reproductive performance and culling in primiparous Swedish cattle. Preventive Veterinary Medicine 9: 59-74.

12. Oversen E (1992). Milking ability in relation to size and shape of teats. Animal Production 15: 251-257.

13. Radostits OM and Blood DC (1985). Herd Health: A Textbook of Health and Production Management of Agricultural Animals. $1^{\text {st }}$ Ed. W.B. Saunders Co., Philadelphia, pp. 165-167.

14. Rahaman MS, Nooruddin M and Rahman MM (1997). Prevalence and distribution of mastitis in crossbred and exotic cows. The Bangladesh Veterinarian 14: 15-18.

15. Rahman MM, Zaman MM and Samad MA (1986). Relationship between udder characteristics and milk yield in German Blackpied cows. Bangladesh Journal of Animal Science 15: 53-61.

16. Rodostits OM, Blood DC and Gay CC (1995). Veterinary Medicine: A textbook of the diseases of cattle, shape, pigs, goats and horses. $8^{\text {th }}$ ed. Bailliere-Tindall, London, pp. 601, 614-615.

17. Rogers GW and Spencer SB (1991). Relationship among udder and teat morphology and milking characteristics. Journal of Dairy Science 74: 4189-4194.

18. Rouine K (1975). Observations on teat stenosis. Nordisk Veterinaria 27: 107-111.

19. Ruban YD, Vard AM and Povo VV (1993). Breeding cows for suitability to machine milking and for mastitis resistance. Sel' shkho zyaistvennaya- Biologiya 2: 28-33.

20. Saloniemi H (1980). Udder diseases in dairy cows, field observations on incidence, somatic and environmental factors, and control. Journal of Scientific Agricultural Society Finland 52: 85-184.

21. Schlesselman JJ and PD Stolley (1982). Case control studies: Design, Conduct, Analysis. $1^{\text {st }}$ Ed. Oxford University Press, Oxford. pp. 176-179.

22. Shukla SK, Dixit VP, Thapliyal DC, Garg SK and Kumar A (1997). A note on the incidence of bovine mastitis in relation to teat shape size and quarters affected. Indian Veterinary Journal 74: 989-990.

23. Slettbakk T, Jorstad A, Farver TB and Hird DW (1990). Impact of milking characteristics and teat morphology on somatic cell counts in first lactation Norwegian cattle. Preventive Veterinary Medicine 8: 253- 267.

24. Sutradhar S (1999). Morphological relationship of udder and teats with mastitis and milk yield of crossbred dairy cows. MS Thesis. Department of Surgery and Obstetrics, Faculty of Veterinary Science, Bangladesh Agricultural University, Mymensingh. pp. 93.

25. Van Schaik VG, Green LE, Guzman D, Esparza H and Tadich N (2005). Risk factors for bulk milk somatic cell counts and total bacterial counts in smallholder dairy farms in the $10^{\text {th }}$ region of Chile. Preventive Veterinary Medicine 67: 1-17.

26. Wittorff KE, Pico G, Heird CE and Rakes JM (1987). The effects of teat end shape, milking rate and lactation variables on somatic cell count in lactating Holstein cows. Journal of Dairy Science 70: 242. 